Стана С. РИСТИЋ*

Институт за српски језик САНУ, Београд

Ивана В. ЛАЗИЋ КОЮИК

Институт за српски језик САНУ, Београд

\title{
РАЗВОЈНЕ ТЕНДЕНЦИЈЕ ЕТНОЛИНГВИСТИКЕ У САВРЕМЕНОЈ СРПСКОЈ ЛИНГВИСТИЦИ**
}

\begin{abstract}
У раду ће се представити развој етнолингвистике у Србији на ширем плану двеју независних, комплементарних етнолингвистичких школа: руске и пољске, који се може пратити од последње деценије 20. века па све до данашњег времена, у периоду откада се појављују први радови који се баве етнолингвистичким проблемима применом етнолингвистичке методе у комбинацији са другим лингвистичким методама. Циљ је да се представе досадашњи резултати етнолингвистичких истраживања у Србији у контексту словенске етнолингвистике и сличних дисциплина антрополошке оријентације, да се уоче фазе и тенденције њиховог развоја и да се на основу њих установи будући правац заједничког развоја који би водио заснивању јединствене српске етнолингвистичке школе.

Кључне речи: етнолингвистика, заснивање српске етнолингвистичке школе, етнолингвистички теоријско-методолошки приступи, српски језик.
\end{abstract}

\section{1. Преглед стања у српској лингвистици}

Развој етнолингвистике у Србији може се пратити на ширем словенском плану двеју независних, комплементарних етнолингвистичких школа - руске и пољске - од краја осамдесетих година 20. века, када се у српској средини појављују први радови који се баве етнолингвистичким проблемима применом етнолингвистичке методе у комбинацији са другим лингвистичким методама и различитим приступима (етимолошким, дијалектолошким, когнитивним, концептуалним, етнографским, фолклористичким, митолошким, антрополошким). Стање и резултати етнолингвистичких истраживања у Србији до сада су сумирани у више прегледних радова

\footnotetext{
*stana.ristic@isj.sanu.ac.rs

***:Рад је урађен у оквиру пројекта МПНТР-ОН 178009.
} 
домаћих аутора, у којима је обухваћен период од почетака развоја етнолингвистике у Србији 80-их год. 20. века па до прве деценије 21. века (Ilić 2002, Ajdaczyć 2006 (Ајдачић 2017), Сикимић 2006, 2007, Илић, Ђурић-Миловановић 2013), што пружа могућност да се издвоје досадашње фазе у развоју српске етнолингвистике и представе основне развојне тенденције у најновијем периоду друге деценије 21. века.

\section{2. Претпочетна (сакупљачка) фаза - од Вука до друге половине}

20. века

Историјат условно речено „српске етнолингвистике” од Вука до друге половине 20. века показује да за славистичку етнолингвистику посебну вредност имају бројни, богати и исцрпни материјали у збиркама Вука Караџића, Вука Врчевића, Павела Ровинског, Ивана Јастребова, Тихомира Ђорђевића, Татомира Вукановића, Миленка Филиповића и др., у којима су дати подаци драгоцени за етнолошко-фолклористичка и лингвистичка истраживања. ${ }^{1}$ Значајни су и они, релативно ретки записи обичаја рађени у локалном дијалекту, какве је правио, на пример, Владимир Ардалић, Србин из далматинског залеђа на прелазу 19. и 20. века, а исто тако и грађа објављивана у периодичним публикацијама Гласник Етнографског музеја, Српски етнографски зборник Српске краљевске академије (САНУ), Српски дијалектолошки зборник из Београда, Гласник Земаљског музеја из Сарајева, Зборник за народни живот и обичаје јужних Славена из Загреба.

У другој половини 20. века сакупљање грађе из традиционалне баштине из политичких разлога донекле је маргинализовано у водећим установама у Србији као што су Етнографски институт и Етнографски музеј, док је ситуација у дијалектологији била повољнија захваљујући ангажовању сарадника Института за српски (српскохрватски) језик САНУ.

\section{3. Рани период развоја - утицај московске етнолингвистичке школе и реконструктивни приступ}

Осамдесетих година 20. века, под утицајем П. Ивића у области дијалектологије, етимологије и ономастике, формирала се група лингвиста који су у својим истраживањима почели примењивати достигнућа московске етнолингвистичке школе (исп. Ајдачић 2017: 81-82). У питању су радови сарадника Етимолошког одсека Института за српски језик: Александра Ломе, Јасне Влајић-Поповић, Марте Бјелетић и Биљане Сикимић, која је истраживања овог типа наставила у Балканолошком институту до данас са групом сарадника. Нешто раније на новосадском Филозофском факултету, на садашњем Одсеку за српски језик и лингвистику, започиње систематско истраживање лексике из области српске материјалне културе Војводине групе

\footnotetext{
${ }^{1}$ Због ограниченог обима у раду не могу бити наведени библиографски подаци за ауторе и референце који се помињу.
} 
дијалектолога окупљених око Гордане Вуковић, који успешно примењују теоријско-методолошке поставке ове руске школе у домену семантичких поља и тематских група према сачињеним упитницима (резултати су монографије Српскохрватска лексика рибарства, 1977, Војвођанска коларска терминологија, 1984, Пастирска терминологија Срема, 1985, Терминологија куће и покућства у Војводини, 1988), а касније и лексике других српских (углавном руралних) крајева, нарочито југоисточне Србије на Катедри за српски језик и књижевност Филозофског факултета у Нишу под руководством Недељка Богдановића. Овакво прикупљање лексике актуелно је и данас углавном у раду млађих сарадника и студената, а резултати се објављују у виду прилога у часописима Прилози проучавању језика (Нови Сад) и Језички прилози (Ниш).

Вишеструко значајна година за развој етнолингвистике у Србији на пољу теоријске мисли била је 1996, када се појавио први број етнолингвистичког годишњака Кодови словенских култура ${ }^{2}$, који је био посвећен пре свега традиционалној духовној култури словенских народа, и то са становишта фолклора у духу руске семиотичке школе (Ајдачић 2017: 83). Посебан значај овог часописа огледа се у чињеници да је у њему установљен заједнички методолошки приступ који се препознаје и означава као „реконструктивни”, а у развоју етнолингвистике у Србији наводи се као рани период њеног развоја који је касније отишао у више праваца. Његова основна особина је да се етимолошка и дијалектолошка истраживања повезују са фолклористичким и етнографским подацима према начелима московске етнолингвистичке школе Н. И. Толстоја у циљу реконструкције прасловенског/општесловенског стања. На тај начин се етимолошка и теренска истраживања допуњују упоредно-историјском анализом која се заснива на прикупљеном материјалу.

Словенској етнолингвистици у смислу методе, у овом периоду, највише припадају радови Љубинка Раденковића, који се бави демонологијом, док је највише домете етнолингвистичке реконструкције постигао у својим радовима А. Лома (Сикимић 2007: 40).

\section{4. Савремено стање - правци развоја}

Касније, у наредном периоду српска етнолингвистика развила се у више праваца, од којих су данас значајније резултате дала теренска истраживања традиционалне материјалне и духовне културе заснована на традицији московске етнолингвистичке школе (тимови на пројектима Балканолошког института и на пројекту Матице српске); когнитивистичка истраживања, и то у индивидуалним приступима (Људмила Поповић (исп. Сикимић 2007: 40), Стана Ристић, Милана Радић-Дугоњић (коауторска монографија Реч. Смисао. Сазнање, 1999), С. Ристић (2015, монографија у којој су представљени културни концепти чАСт, СРАМОТА, СТИД, МАЈКА, дом, домовинА, лЕПОТА)), или у приступима под утицајем лублинске етнолингвистичке школе (Дејан Ајдачић, Марија Стефановић, С. Ристић, Ивана Лазић Коњик, Рајна

\footnotetext{
2 Уз још четири књиге повезане са етнолингвистиком: две монографије љ. Раденковића, једна Б. Сикимић и једна М. Детелић (Ајдачић 2017: 83).
} 
Драгићевић, Маријана Богдановић); а затим и лингвокултуролошки приступи (Р. Драгићевић, Ксенија Кончаревић).

Етнолингвистичка теренска истраживања интердисциплинарног приступа организована су почетком и у првој деценији 21. века и у Институту за српски језик у оквиру два пројекта, „Словенски говори на Косову и Метохији” и „Језик и идентитет у Републици Србији”, под руководством С. Ристић, са циљем заснивања звучног архива намењеног за даља истраживања, поред осталог, и за истраживања из области урбане етнолингвистике. ${ }^{3}$ За ову област значајно је и истраживање говора Новог Сада, објављено у две монографије са транскриптом и аудио-материјалом $(2009,2011)$.

У Балканолошком институту САНУ обављају се теренска истраживања мултиетничких, -језичких и -конфесионалних средина у централној и југоисточној Европи и прикупља база података аудио-материјала. Овај тим истраживача предводи Б. Сикимић, а према наводима самих сарадника, у свом досадашњем раду прешли су пут од ране фазе, под утицајем руске етнолингвистичке школе, до најновије фазе „антропологизације” етнолингвистике, под утицајем америчке и англосаксонске антрополошке лингвистике (Илић, Ђурић-Миловановић 2013: 79-82).

У најновије време, на пројекту МС под руководством Софије Милорадовић, раде се истраживања посвећена духовној култури Војводине, мултиетничке, -језичке и -конфесионалне заједнице овог значајног региона Србије, везана за културу исхране већинског српског становништва (термини и етнокултурни контекст у коме дати термини функционишу), чији су резултати досадашњег рада објављени у два тематска зборника $(2011,2014)$. Већи број прикупљених назива појединих реалема могао би послужити за унапређење рада у области ареалне лингвистике, у овом случају етнолингвистичке (етнодијалектолошке) географије Војводине, као и за израду етнолингвистичких карата са изолексама које сведоче о етнокултуролошким датостима на овом простору, што је значајно за ширу етнолингвистичку перспективу међуетничких и међујезичких контаката на простору Војводине.

Материјали сакупљени на терену и етнолингвистички приступи, поред наведених резултата, наговештавају и планирану израду специјалних речника: културолошког, из сфере исхране у обредној пракси (Недељков 2014), етнодијалекатског рекцијског речника глаголских лексема релевантних за културу обредне исхране у Војводини (Милорадовић 2014), етнолингвистичког речника чипских Срба (Илић $2005)$ и речника српских народних песама са етнолингвистичким карактеристикама (Лазић-Коњик 2017).

За ситуацију у савременом српском језику не сме се пренебрегнути ни богата језичка и етно-језичка грађа прикупљена за Речник САНУ из писаних и књижевних извора и из бројних народних говора и сам РСАНУ као важан извор за етнолингвистичка проучавања, на шта није указано у поменутим прегледним радовима, али је више пута показано и истакнуто у појединачним радовима истраживача (в. нпр. Ристић, Лазић-Коњик 2016). Целокупан материјал РСАНУ са примерима употребе, фразеолошким и колокационим спојевима, синонимним низовима и творбеним

\footnotetext{
${ }^{3}$ О урбаној етнолингвистици в. Пипер 2008, као и запажање Р. Бугарског (2005: 26) о истраживањима овог типа: „Ovaj naziv [етнолигвистика] ... pristaje i nekim drugim domenima - recimo, proučavanju jezičkog izraza savremenih subkultura i paraknjiževnih žanrova”.
} 
дериватима, пружа релевантне податке не само за граматичке и семантичке већ и за друге, културне и аксиолошке аспекте значења, што посебно долази до изражаја у радовима истраживача оријентисаних ка когнитивној етнолингвистици под утицајем лублинске етнолингвистичке школе.

\section{5. Словенски контекст - руска и пољска етнолингвистика и српска етнолингвистика данас}

Стање словенске етнолингвистике на прелазу векова, према запажањима Б. Сикимић (2005: 236), карактеришу две наизглед контрадикторне тенденције - фрагментација и интердисциплинарност. За њен даљи развој и за развој етнолингвистике у Србији важна су питања постављена на Славистичком конгресу у Охриду на која се покушало одговорити у бројним радовима у лублинском часопису Етновингвистика 18 (2006), као што су: у ком светлу се могу данас сагледати домети словенске етнолингвистике као пројекта који је почетно био намењен реконструкцији словенске културе, и питање даљег правца у развоју словенске етнолингвистике.

Чини се да су постављена питања, као и терминолошко раздвајање блиских интердисциплинарних истраживања језика и културе, сувишна и да се савремени истраживачи етнолингвистичког усмерења врте у кругу покушавајући да учине искорак из дисциплине, чији су темељи постављени још у 19. веку, било да је у питању словенска етнолингвистика или англоамеричка антрополошка лингвистика. Ми се у том смислу позивамо на радове Н. Толстоја (1995), Р. Бугарског (2005) и С. Толстој (Толстая 2013).

У раду Н. Толстоја представљени су темељи европске и америчке етнолингвистике, засновани у првој половини 20. века, и одређени су различити правци и динамика њеног развоја, како у погледу избора материјала, тако и у погледу избора полазних приступа у његовој анализи, као и различитог комбиновања интердисциплинарних приступа (32-37). Осим тога, могло би се рећи да се у раду овог аутора могу наћи и неки одговори на наведена постављена питања (37-46), како у дефиницији ове дисциплине на „широком” и „суженом” плану, тако и у одређивању перспективе њеног даљег развоја. Према Н. Толстоју: „На широком плану етнолингвистика укључује у себе дијалектологију, језик фолклора и део историје језика, повезан са историјском дијалектологијом и културном и етничком историјом народа, и [...] све аспекте изучавања језика као социјалне појаве” (37). „У суженом и специјализованом схватању” ова дисциплина се одређује као „грана науке о језику која поставља и решава проблеме језика и етноса, језика и културе, језика и народног менталитета, језика и митологије и сл.” (39). Али се, према овом аутору, развој (етно)лингвистике не зауставља у постављеним „ширим” и ,ужим” границама, него она поново „одређује своје границе, задатке, свој предмет и материјал. Могуће је да ће временом лингвисти доћи до јаснијег или другачијег схватања. Безусловно је [...] да је и сада, у наше време, допустиво и чак плодотворно различито схватање етнолингвистике”. У складу с тим, Н. Толстој предлаже још два одређења етнолингвистике: као део лингвистике „чији је објекат језик и његов однос према култури 
народа” (45) или „као комплексна дисциплина, чији је предмет проучавања 'план садржаја' културе, народне психологије и митологије, независно од средства њиховог формалног оваплоћења (реч, предмет, обред, представа и сл.)”, при чему се истиче да се овакво проучавање „обавља првенствено или искључиво лингвистичким методама" (46). ${ }^{4}$

Део одговора на постављена питања налазимо и у књизи Р. Бугарског у којој ce, поред представљеног утемељења америчке и европске лингвистике, широко одређује предмет етнолингвистике и њено преплитање са блиским дисциплинама (2005: 25-26).

Ипак, праве одговоре на постављена питања налазимо у раду С. Толстој (2013), и то како у одређивању предмета етнолингвистике, тако и у перспективи њеног развоја у више праваца и укључивања у нове актуелне токове, што је засновано на интердисциплинарном приступу који омогућава не само комбинацију различитих метода него и обједињавање резултата и рад истраживача сродних хуманистичких дисциплина на заједничким пројектима. Предмет изучавања етнолингвистике је, према овој ауторки, целокупна народна култура, сви видови жанрова и форми: вербални (лексика и фразеологија, паремиологија, фолклорни текстови), обреди, веровања и др. (Толстая 2013: 68). Принципијелна блискост културе и језика и њихових знаковних система омогућава примену концептуалног апарата и методе лингвистичког истраживања материјала традиционалне духовне културе, почев од лингвистичке географије, језичке реконструкције, семантике и синтаксе; затим појмова и метода лингвистичке прагматике, теорије говорних чинова, когнитивне лингвистике и концептуалне анализе. Ауторка истиче сличности између јединица језика и јединица културе: језичке јединице се одликују културном семантиком, док се јединице културе идентификују лингвистичким појмовима (69). Ипак, знаци језика културе се разликују од језичких знакова (70). ${ }^{5}$ Полазећи са овог становишта, московска етнолингвистичка школа доследно инсистира на наведеним разликама између језичких знакова и знакова језика културе, уважавајући и њихову међусобну сличност и веома расплинуту, тешко одредиву границу између њих. По томе се разликује од ставова идејно веома блиске лублинске етнолингвистичке школе, која заступа став да сва културна значења било ког вида улазе у језичку семантику која се именује / исказује речима а реализује у виду језичких стереотипа. Поводом тих разлика годинама се води дискусија између московских етнолингвиста и лублинске групе етнолингвиста. Што се тиче праваца даљег развоја и резултата рада руских етнолингвиста, како ауторка истиче, паралелно са радом на речнику, развија се етнолингвистичка ареалогија, израда тематских монографија, разматрање теоријских питања етнолингвистике и фолклористике (79).

\footnotetext{
${ }^{4}$ Чини нам се да на овом одређењу лингвистике, односно на овако успостављеном односу између језика и културе, Ј. Бартмињски заснива другачији правац у развоју етнолингвистике у односу на московску етнолингвистичку школу, која, како ће се видети код. С. Толстој, инсистира на разграничењима ових двају блиских области - језика и културе.

5 „Oblast kulture toliko je razlivena, i sama po sebi i u vezi s jezikom, da nema jedne discipline koja bi mogla pretendovati da sve to pokrije. Pojedina tematska čvorišta iz tog širokog opsega mogla bi spadati u nadležnost antropološke lingvistike, kulturne antropologije, sociologije jezika, socijalne psihologije, kulturologije i drugih interdisciplinarnih naučnih područja”" (Бугарски 2005: 25).
} 
Пољска етнолингвистика коју предводи Ј. Бартмињски, по многим својим замислима, а највише у речнику стереотипа и народних симбола (1996-), блиска је руској, али се временом ипак дистанцирала од првобитно прихваћене дијалектолошке етнолингвистике Н. Толстоја. Програмским радом Ј. Бартмињског она је усмеравана у правцу тражења „културе у језику”, у семантичком слоју језичких форми (Bartmiński 2016: 7), због чега су се у истраживачком фокусу, поред различитих фолклорних врста, нашли проблеми језичке слике света, и у последње време детаљне студије о семантици одабраних културних концепата / вредности. Заокрет ка аксиолошкој димензији профилисао је лублинску етнолингвистку (што се данас означава називом когнитивна), а њен карактер највидљивији је у раду међународног семинара ЕУРОЈОС под руководством Ј. Бартмињског, чији учесници раде на Аксиолошком лексикону Словена и њихових суседа. Актуелни рад на Лексикону тренутно је и најважнији задатак етнолингвистичког програма културолошке лингвистике, по речима његовог уредника, по чему се лублинска когнитивна етнолингвистика све више приближава западној културолошкој лингвистици антрополошког усмерења (Bartmiński 2016: 19-20, 24).

Српски истраживачки тим (Д. Ајдачић, С. Ристић и И. Лазић-Коњик, М. Стефановић, Р. Драгићевић и М. Богдановић) активно учествује у раду семинара ЕУРОЈОС. Први импулси интересовања за лублинску етнолингвистику у српској средини потекли су од Д. Ајдачића, који је иницирао и омогућио превођење изабраних радова Ј. Бартмињског у књизи Језик. Слика. Свет, 2011. Књига је наишла на добар пријем код српских истраживача, који су се одмах укључили у рад поменутог семинара. Радове припремљене за Аксиолошки лексикон и зборник ЕУРОЈОС-а, у којима се анализирају називи вредности, тзв. културни концепти, према методологији лублинске етнолингвистичке школе, као и друге сличне прилоге, Д. Ајдачић је објединио у посебном зборнику, О вредностима у српском језику, 2015. Овај Зборник на добар начин показује у ком правцу су кренула српска етнолингвистичка истраживања когнитивног усмерења, под утицајем лублинског приступа, о чему J. Бартмињски (2015: 8) констатује следеће:

\footnotetext{
Изазов за истраживаче назива вредности представља проналажење метода анализе назива вредности, које одговарају њиховој особеној природи и начину функционисања тих назива у дискурсу, у комуникацији. У прилозима представљеним у овом тому, аутори су предузели истраживање вредности на нов начин, ослоњен, с једне стране, на добру структуралистичку традицију, а с друге стране, они се обраћају ставовима антрополошко-културолошке и когнитивне лиингвистике.
}

Укључивање српских истраживача на пројекат ЕУРОЈОС резултирало је такође успостављањем директне сарадње између пољских и српских етнолингвиста у виду билатералног пројекта Кључни конщепти српске и пољске аксиосфере на словенском плану, који је заснован у Институту за српски језик САНУ и Институту за славистику ПАН крајем 2016. год. Овај пројекат пружа могућности да се будућа етнолингвистичка истраживања назива вредности у српској средини одвијају систематски и плански, у складу са ширим истраживачким захтевима и потребама српске и словенске етнолингвистике. 


\section{6. Словенска, западна и српска етнолингвистика - на путу ка јединству}

Текућа дебата о статусу и перспективама словенске етнолингвистике нашла је своје место у радовима белгијског слависте Питера Пласа, који је разматрао њене сличности и разлике са паралелним правцима у савременој англоамеричкој лингвистичкој антропологији (Сикимић 2007: 37). Разлике између словенских етнолингвистичких школа у поређењу са англоамеричком (лингвистичком) антропологијом односе се на оријентисаност словенске етнолингвистике ка теренским и архивским истраживањима махом руралних заједница и ка реконструкцији најстаријих етнодијалекатских модела и изради етнодијалекатских речника, а као синтезе ових истраживања настају енциклопедијски речници (Славянские древности; Словенска митологија), речници етнокултурних стереотипа (Stownik stereotypów i symboli ludowych 1-2) или дијалекатски и етнојезички атласи (Мальй диалектологический атлас балканских языков). У антрополошкој лингвистици, с друге стране, наглашена је синхрона и прагматичка димензија значења, тј. интересовање за конкретни друштвени контекст и идеолошку раван значења, при чему су предмет изучавања не само етничке заједнице него и језичке, социјалне, родне и др. (Илић, Ђурић-Миловановић 2013: 75-77).

Проблем међусобног поређења и приближавања словенске и англоамеричке етнолингвистике у смислу заснивања и праваца даљег развоја, поред наведених разлика, представља и употреба различитих назива у различитим срединама за иста или слична усмерења. Терминолошку забуну и нестабилност у именовању англоамеричке етнолингвистике илуструју термини који су у оптицају: етнолингвистика, сочиолингвистика, антрополошка лингвистика, лингвистичка антропологија, културна лингвистика (Илић, Ђурић-Миловановић 2013: 74). С друге стране, у словенској етнолингвистици, поред овог назива, у употреби су и културолошка лингвистика и лингвокултурологија, антрополошка лингвистика, антрополошко-културолошка лингвистика, лингвистичка антропологија (Бартмињски 2011: 11).

Могући пут сарадње између словенске етнолингвистике и западне антрополошке етнолингвистике Ј. Бартмињски види у аксиолошко-културолошкој оријентацији словенске етнолингвистике и изучавању семантике назива вредности одређене друштвене заједнице.

Процес „антропологизације” етнолингвистике у Србији добија своје обрисе такође у радовима Б. Сикимић, као и других слависта (исп. Сикимић 2007: 37). Данас у словенском свету, и у Србији, већи број активних етнолингвиста припада „антрополошком” усмерењу, што је резултат значајног искуства стеченог радом на терену. Дошло се до тога да је веома важно да истраживач буде осетљив на реално стање на терену, да се окрене друштвеној маргини и процесу промена, чији је почетни импулс дала руска етнолингвистичка географија и израда адекватног упитника. У антрополошкој лингвистици привилеговано место заузимају теренска истраживања, а највише се користе методе полуструктурираног, квалитативног интервјуа и учесничког посматрања, методе анкете, визуелне антропологије (фотографија, видео-снимак, цртеж), као и методе архивског истраживања (Илић, Ђурић- 
-Миловановић 2013: 79). Овакав антрополошки приступ налазимо у новијем раду Б. Сикимић (2014).

На крају овог уопштеног прегледа развоја српске етнолингвистике у контексту словенске етнолингвистике, њихови развојни путеви сажето се могу представити концизним формулацијама Б. Сикимић и Ј. Бартмињског - од реконструкције културе до теренских истраживања (Сикимић 2006, 2007) и - од дијалектолошке до когнитивне етнолингистике (Бартмињски 2016).

\section{7. Перспективе у даљем развоју српске етнолингвистике}

Претходни преглед стања у српској и словенској етнолингвистици указује на то да се, за разлику од профилисаних етнолингвистичких школа (московске и лублинске), у српској етнолингвистици та профилисаност још не може назрети нити прогнозирати док се истраживачи овог усмерења не окупе у некој институцији или око једног широко заснованог програма са више различитих пројеката. Представљени „живи” пројекат МС исувише је ограничио своје просторно и тематско поље истраживања. Већу шансу за обједињавање око јединствене методологије за сада пружа пројекат „Интердисциплинарно истраживање културног и језичког наслеђа Србије и израда мултимедијалног интернет портала Појмовник српске културе" (http://www. etno-institut.co.rs/cir/pojmovnik/pojmovnik.php), са више планираних и, за садашње прилике, преамбициозних циљева, као што су: осавремењивање научне праксе на пољу етнологије, науке о језику и других хуманистичких дисциплина, изградња дигиталне инфраструктуре и формирање репрезентативног интернет-портала, израда дигиталног мултимедијалног тезауруса - лексикографско-енциклопедијске базе отворене за нове садржаје. Већа извесност за интегрисани даљи развој српске етнолингвистике може се очекивати од чињенице да је етнолингвистика уведена као наставни предмет на неке факултете у Србији. Студијски програм факултета ФИЛУМ у Крагујевцу за овај предмет (http://www.filum.kg.ac.rs/dokumenta/tabele_predmeta/ OAS-Srpski/Etnolingvistika.pdf) заправо показује добре начине интеграције кроз одређивање односа етнолингвистике према блиским дисциплинама: антропологији, етнографији, социолингвистици; кроз различите видове узајамности језика и материјалне и духовне културе, језика и народног менталитета, језика и етногенезе и етничке припадности, језика и народног стваралаштва; кроз проучавање идиома усменог и писаног језика, вишејезичности и билингвизма, као и кроз тенденције језичког развоја, и то на материјалу писаних извора и на материјалу прикупљеног на терену. Студијски програм обухвата репрезентативан списак актуелне етнолингвистичке литературе, тако да се и по садржају предмета и по литератури може очекивати утицај овако конципираног програма и на ваннаставно - истраживачко поље. То би, уз наведене досадашње резултате и њихово критичко сагледавање, могло значајно утицати на развој етнолингвистике у Србији у наредном периоду и њено профилисање на широко заснованој јединственој методологији заједничког програма, који би се могао реализовати у више различитих компатибилних пројеката кроз непрекидну сарадњу истраживача из ове области, и то у више започетих 
праваца: лексикографски рад (израда разних типова речника, лексикона, појмовника), картографисање истражених језичко-културних датости (ареална етнолингвистика), израда тематских монографија, даљи рад на започетим заједничким домаћим и међународним пројектима, као и у другим видовима међународне сарадње (организовање конференција, семинара, студијских боравка и сл.).

\section{Литература}

Ајдачић Д. „Етнолингвистика у Србији.” Слово Славија - Етнолингвистика и поредбена фразеологија. Београд: Алма, 2017: стр. 81-89.

Бартмињски Ј. Језик. Слика. Свет. Прир. Д. Ајдачић. Прев. М. Бјелетић. Београд: SlovoSlavia, 2011.

Бартмињски Ј. „Уводна реч.” Ајдачић Д. (ур.). О вредностима у српском језику. Београд, Алма, 2015: стр. 7-8.

Илић М. „Ка етнолингвистичком речнику чипских Срба.” Становчић В. (ур.). Положај и идентитет српске мањине у југоисточној и изентралној Европи. Научни скупови, књ. СІХ, Одељење друштвених наука, књ. 25. Београд: САНУ, 2005: стр. 315-339.

Илић М., Ђурић-Миловановић А. „Коме треба антрополошка лингвистика у Србији данас? Пример креирања Дигиталног звучног архива Балканолошког института САНУ.” Етнолошко-антрополошке свеске, 21, (н.с.) 10, 2013: стр. 73-89.

Лазић-Коњик И. „Ка речнику језика фолклора.” Драгићевић Р. (ур.). Путевима речи. Београд: Филолошки факултет Универзитета у Београду, 2017: стр. 297-312.

Милорадовић С. „Етнодијалектолошки приступ култури исхране кроз обредну праксу. На материјалу из Ердевика и Парага.” Милорадовић С. (ур.). Обредна пракса - „речима о храни”. На материјалу из српских говора Војводине. Нови Сад: Матица српска, 2014: стр. 25-47.

Недељков Љ. „Испитивање ритуалне кулинарске лексике Војводине - допринос упознавању духовне културе.” Милорадовић С. (ур.). Обредна пракса - ,речима о храни”. На материјалу из српских говора Војводине. Нови Сад: Матица српска, 2014: стр. 11-23.

Пипер П. „О урбаној етнолингвистици.” Пипер П., Раденковић Љ. (ур.). Етнолингвистичка проучавања српског и других словенских језика. Српски језик у светлу савремених лингвистичких теорија, Књига 3, Београд: САНУ, 2008: стр. 311-323.

Ристић С., Лазић-Коњик И. „Репрезентативност Речника САНУ за етнолингвистичка истраживања: од лексикографске ка когнитивној дефиницији.” Ристић С., Лазић Коњик И., Ивановић Н. (ур.). Лексикологија и лексикографија у светлу савремених приступа. Београд: Институт за српски језик САНУ, 2016: стр. 377-394.

Сикимић Б. „Истраживач је присутан: храна као тема и повод за разговор и размишљање.” Милорадовић С. (ур.). Обредна пракса - „речима о храни”. На материјалу из српских говора Војводине. Нови Сад: Матица српска, 2014: стр. 97-111. 
Сикимић Б. „Етнолингвистика у Србији: од реконструкције културе до теренских истраживања.” Свет речи, год. ХІ, бр. 23-24, 2007: стр. 37-42.

Сикимић Б. „Интердисциплинарни приступ у истраживању традиционалне духовне културе данас.” Неговање и заштита нематеријалне баштине у Србији, Стручни скуп о нематеријалној баштини, Зборник радова 2, Београд, 2006: стр. 23-26.

Сикимић Б. „Изазов теренског рада - етнолингвистика или антрополошка лингвистика?” Зборник радова Етнографског института САНУ, 21, 2005: стр. 235-244.

Толстая М. С. „Постулаты московской этнолингвистики.” Толстой Н. И., Толстая С. М. Славянская этнолингвистика: вопросы теории. Москва: РАН, Институт славяноведения 2013: стр. 67-82.

Толстој Н. И. „Етнолингвистика у кругу хуманистичких дисциплина.” Језик словенске културе. Избор и поговор Љ. Раденковић. Прев. Љ. Јоксимовић. Просвета, Ниш, 1995: стр. 31-46.

Ajdaczyć D. „Etnolingwistyka w Serbii.” Etnolingwistyka, 18, 2006: стр. 67-75. Bartmiński J. „O aktualnych zadaniach etnolingwistyki.” Etnolingwistyka, 28, 2016: стр. $7-29$.

Bugarski R. Jezik i kultura. Beograd: Biblioteka XX vek, 2005.

Ilić M. „Etnolingvistika u Srbiji.” Зборник Матище српске за славистику, 62, 2002: стр. 211-234.

\author{
Стана С. Ристич \\ Ивана В. Лазич Коник \\ ТЕНДЕНЦИИ РАЗВИТИЯ ЭТНОЛИНГВИСТИКИ В СОВРЕМЕННОЙ \\ СЕРБСКОЙ ЛИНГВИСТИКЕ
}

\begin{abstract}
Резюме
В работе представлено развитие этнолингвистики в Сербии в широком контексте двух независимых взаимодополняющих этнолингвистических школ, русской и польской, которое прослежено, начиная с последнего десятилетия XX века вплоть до настоящего времени, с момента, когда появляются первые работы, которые занимаются этнолингвистическими проблемами путем применения этнолингвистического метода в сочетании с другими лингвистическими методами. Цель данной работы - представить достигнутые до сих пор результаты этнолингвистических исследований в Сербии в контексте славянской этнолингвистики и сходных дисциплин антропологической ориентации, чтобы обозначить фазы и тенденции их развития и на их основании установить будущее направление этого развития. Отправной точкой стал вопрос, в какой мере и каким способом применяются теоретико-методологические положения московской или люблинской этнолингвистической школы в исследованиях сербских лингвистов. В работе рассмотрены достигнутые результаты и критические отзывы на проделанную работу. Сделан вывод, что на основании исследованной этнолингвистической данности, а также начатых совместных проектов и образовательной программы предмета «Этнолингвистика» на факультетах уже сейчас могут
\end{abstract}


быть определены некоторые совместные тенденции в развитии сербской этнолингвистики в предстоящий период. Сделаны предложения ее профилирования по уникальной методологии совместной программы на широкой базе, которые могли бы быть реализованы в нескольких различных совместимых проектах через непрерывное отечественное и международное сотрудничество исследователей из этой области, при этом в нескольких начатых направлениях. Подчеркнуто, что это были бы хорошие предпосылки для создания уникальной сербской этнолингвистической школы.

Ключевые слова: этнолингвистика, создание сербской этнолингвистической школы, этнолингвистические теоретико-методологические подходы, сербский язык. 